\title{
Different Reasons to Play Games in an English Language Class
}

\author{
Julia Sevy-Biloon $^{1}$ \\ ${ }^{1}$ Universidad Nacional de Educacion (UNAE), Ecuador \\ Correspondence: Julia Sevy-Biloon, Universidad Nacional de Educacion (UNAE), Ecuador.
}

Received: November 18, 2016

Accepted: December 6, 2016 Online Published: December 13, 2016

doi:10.11114/jets.v5i1.1967

URL: http://dx.doi.org/10.11114/jets.v5i1.1967

\begin{abstract}
English language students at the Universidad Nacional de Educacion (UNAE) in Ecuador tend to have various learning styles and have a hard time being motivated to not only learn, but also remember the correct form of English language being taught in the classroom. It is mandatory for these students to learn English; therefore many do not have intrinsic reasons for wanting to study English. This study focused on a group of 30 fourth semester beginner EFL university students studying to be elementary school teachers. Through the research conducted, the author investigated how game play in the classroom could intrinsically motivate, promote different learning styles and advance English language learning when students do not have an initial want or understanding of the need to learn the language other than the fact that it is a mandatory subject in their university. Games were used throughout the course to reinforce grammar and vocabulary, promote multiple skill learning while using diverse teaching styles to create an environment, which independently motivated the pupils of the class to not only want to learn, but also to internalize the language. Students were given various questionnaires, an online quiz and assessment materials to assist the teacher in finding the results for the study. Through the findings of the study these tools produced results that demonstrated the importance of games as a strategy to use in a language class, with college age students in UNAE. Games helped students increase their speaking, reading, writing and listening skills and at the same time increased their motivation to want and appreciate learning English. They were a specifically useful strategy with this group, because it also aided in authentic learning and made fundamental English language learning more enjoyable.
\end{abstract}

Keywords: educational games, EFL students, language skills, learning styles, intrinsic motivation

\section{Introduction}

There are many different types of activities an educator can choose to use in an English language classroom. The activities being discussed in this paper support and reinforce grammar and vocabulary learning through games. The participants of the study tended to show more interest, have increased motivation and advance in English language learning when games were incorporated into the class on a regular basis. The author and investigator of this study wanted to determine if utilizing the strategy of games in the classroom for college age students increased and promoted English language learning while at the same time motivating them to advance in the language learning process even though most of them did not choose or want to learn English in the university. The English teacher recognized this as an important topic of study since most of the students that participated are only taking English because it is a mandatory course in all universities throughout the country. This law can be found in the Reglamento de Regimen Academico Articulo 31 from the Republica Del Ecuador Consejo de Educacion Superior RPC-SE-13-No.051-2013 (n.d.), explicitly explaining how university level students must complete an exam with a B2 level as stated in the Common European framework or they would not be able to further their studies. For the students of this study just English as a compulsory subject is not enough to motivate them to truly want to learn English. The teacher of this group found it important to find strategies to increase the students' aspirations to learn while at the same time promoting language learning.

The technique of game play can be used to reinforce and support the learning process in listening, reading, writing and speaking skills as well as teach to different learning styles. Dunlap (2013) explains how games help the teacher connect grammar, structure, and vocabulary in a classroom setting, while still being associated with real life situations. This is important because it shows a relationship between English language learning and everyday communication and tasks outside of the classroom. There are many different types of games a teacher can introduce into the classroom to support the learning of these skills. The professor of the group discussed in this paper provides various types of didactic games to reinforce combined skill learning in groups or as a whole. The students will play games using the 4 skills to reinforce 
vocabulary and grammar being learned throughout the course. The English teacher will show how playing games not only reinforces the information being taught in the class, but also motivates and helps the students internalize the new information and promote language learning. The teacher can also utilize various techniques to create games that allow students to learn in different forms such as visually, audibly, or physically depending on the types of games the teacher creates and the students participate in.

\subsection{Explanation of Problem}

In this specific class discussed and in the experience of the English teacher, there are many types of learners that can attend an English language class. These students tended to have varying learning styles and it depended on the educator to figure out how to support, develop and advance English language skills as much as possible in the allotted time given. Many of these learners, especially in the groups observed in this paper, do not have an internalized concrete connection or an intrinsic reason for learning English since taking English is a mandatory subject in universities in Ecuador. Many of the participants could not find intrinsic reasons to want to learn English and many of them felt English was too difficult to learn. The author learned through the research that in the students' prior experience many activities previously used were not directed to their learning styles in English language courses. Therefore, for many of the students throughout their school career, English was nothing more than a compulsory subject they must pass, but did not care to learn. The English teacher found games and game play to be the best types of activities to use in the classroom where the research was conducted to overcome this motivational and learning problem.

Through various discussions and interviews with other English Foreign Language (EFL) educators completed by the author it was found that in Ecuador, specifically in Azuay it is a struggle to teach to the various types of learning styles and at the same time intrinsically motivate EFL learners. Students of this study had a hard time expressing the importance of learning English or why it would serve them in the future. Through the research completed in this article and many years of experience teaching ESL, the author has found that the use of games in the classroom is a simple technique to teach to many learning styles over the course period. At the same time this strategy intrinsically motivates the learners to internalize the previous language introduced in the class even when there is little interest expressed by the pupils.

\subsection{Revelance}

Around the world English language educators struggle with finding ways to motivate students and create connections for those students to not only learn English, but also remember it and be motivated to advance in the language process. Among the authors research, games can be seen as an answer to these problems. Different educators from around the world from countries such as the United States, England and Asia all have looked at these problems and used various types of games to solve them. This research can be seen in studies completed by Elliot (2004) in England. She explained how games aided in students language advancement without realizing they were learning. Another paper by Moon and Reifel (2008) in the United States found how games can beneficial in learning and practicing reading skills for young children because they tend to feel more comfortable in the relaxed environment playing games create. Rao (2006) explains that in China games have been used to assist students in learning in new ways to help open their minds. These are just a few of the studies completed around the world to highlight different ways games have been used in an English language classroom. This paper differs in the fact that the research was completed in Latin America and it is looking at how to motivate students who would otherwise choose not to study English as a university course if it was not mandatory. This is clearly important since many college age Latin American EFL teachers and students need motivational, learning and teaching strategies to aid in the English language learning process. This paper demonstrates how games can be this strategy and a positive tool for teachers and for the group of learners being discussed.

\section{Literature Review}

\subsection{Why Games}

Games can be used as a teaching method to reinforce grammar and vocabulary in the language learning process while simultaneously using various English language skills. Games can be created for every aspect of language learning and these types of tasks work to support language skills. As Ersoz (2011) points out it is also very important when deciding on games to use in the classroom to choose ones that fit with the needs and learning styles of the students. It is also important to make sure the games are not too difficult or easy for your students to participate so the game does not decrease student's motivation to learn. Shultz (2014) explains that Krashen's work is about language acquisition, which discusses how work given to the students should be at a level that is understandable to the students, but should still encourage and promote improvement. There are many types of games, which will help motivate students learning intrinsically and extrinsically. It is also possible to use games to create more of an authentic learning environment in the classroom. Sigurðardóttir (2010) explains how games allow students to become independently involved in their individual learning processes while opening up spaces to practice real life experiences in the controlled atmosphere of 
the classroom. He goes onto describe how these types of activities can give students a boost of self-confidence, therefore they are more involved in their learning tasks. Using games in the classroom can also allow the professor to teach more to the different needs of the students depending on their individual learning styles. According to Sigurðardóttir (2010) games can be adapted; therefore students can participate in group activities, physical movement activities, more mental tasks, and visual games allowing the educator to teach directly to the learning styles of the students. Mubaslat (2012) reinforces these ideas by expressing how games are a necessary tool for the classroom to aid in learner motivation and authentic communication between peers.

\subsection{Motivation}

ESL teachers in Ecuador are always looking for ways to promote language learning and at the same time motivate students to learn since language can be difficult to master and internalize when some students in this country do not choose to study English, but must if they want to graduate from university. A strategy to teach English can be to use games as they "are highly motivating since they are amusing and at the same time challenging (Mubaslat, 2012, p. 4)." Games allow students to learn while at the same time have fun. Mubaslat (2012) explains students are motivated by their want to finish first and win. They have a competitive side and this promotes them in advancing in the language learning process. Students are able to learn through games by using the newly introduced grammar or vocabulary in a fun and challenging activity, which they can be intrinsically or extrinsically motivated. Students can be motivated by the need to win the game or receive some sort of prize. They also can feel a connection to what they are learning and become enthusiastic by recognizing the importance of the grammar or vocabulary through play. (Mubaslat, 2012) Not only do educators find games a motivating method for teaching, but Chen (2005) also establishes in his findings how students see that they are more motivated, and are able to internally absorb the information learned in the course when they play games in the classroom to practice English. Games can also create authentic or real learning atmospheres in the classroom through the use of realia or the types of games played.

\subsection{Authentic Learning}

It can be a challenge to bring authentic or real life situations into the classroom so students are able to connect the language they are learning with real life contexts. This can be accomplished through playing certain types of speaking games such the activity of group communication games discussed in this paper. This allows for a more relaxed environment where students can feel as though they are just having a conversation with friends. Lombardi (2007) states that this type of learning is important because it gives learners confidence with the material being taught and ultimately helps in the promotion of the language learning process. It is also pointed out by Deesri (2002) how students can become so engrossed in a game and focused on how to play the game, working as a group and competing to ultimately win that the grammar and vocabulary being used becomes natural since the students are not focused on learning English, but on the task at hand. "Students stop thinking about language and begin using it in a spontaneous and natural manner within the classroom (Deesri, 2002)." Through games students can reinforce and learn many different language skills such as new vocabulary, speaking, listening, grammar, reading and writing. Chen (2005) writes how learning these skills through play creates a context which students can correlate to real life and ultimately helps them to internalize the information and remember how and when to use these tools outside of the classroom.

\subsection{Language Skills}

It can be a difficult task for an ESL teacher to find ways to teach language skills such as reading, writing, listening and speaking in a natural and authentic manner, while motivating the students to advance in the language learning process. For example, from the professors prior experience teaching English in Ecuador students tend to learn vocabulary, but later cannot use it properly when communicating or attempting to practice the other skills in more natural contexts. Huyen and Nga, (2003) illustrate how the use of games allows students to practice using the newly learned vocabulary in contexts that help them internalize the language and give them the tools to use it in other contexts that arise. They go on to explain how vocabulary normally is not difficult for students to learn, however problems occur when they try to use it in proper contexts and remembering the meanings of the new words previously learned. Games allow them to not only learn vocabulary, but also give them a space to use it in a meaningful context, which will help them make connections of how to use these words in the future.

The research completed by Shazhad (2011) gives more evidence that language is best learned through doing and students having an active role in their learning experience through game play. When playing a game it is necessary for each person to be involved or actively participate. This active participation creates an environment where students can give unknowing attention to the specific grammar points, which they are learning or previously learned in class in a natural way. Arikan and Yolagelddili (2011) illustrate how games can support and motivate grammar learning through advancing student's abilities in communication competencies. "In short, games provide learners with an opportunity to drill and practice grammatical rules and forms by presenting them in a communicative way (Arikan \& Yolagelddili, 
2011)". Students who do not have an intrinsic incentive to learn English will ultimately internalize the language unknowingly just through participating in game play in the classroom.

\section{Methodology}

The study was completed over a 5-month period with 30 beginner students in Azogues, Ecuador. These students had English language classes twice a week for two hours each day, for a total of 15 weeks a semester. The students were expected to complete a certain amount of English language skills in these allotted class hours, so they would comply with the Ecuadorian law mentioned above about having to be sufficient at a B2 level at the end of sixth semester of study. The teacher of this group chose to use games in every class to introduce, learn and/or reinforce the grammar and vocabulary the students were obligated to learn. The students played different types of games reinforcing speaking, reading, writing and listening skills to promote language learning in a more natural environment, while motivating them to further English language learning.

\subsection{Research Method}

This study was conducted using a qualitative approach. The research was completed during various classes over two semesters with a group of advanced beginner English language students. Qualitative research was chosen as a means to gather necessary information in an informal manner over a short period of time through unstructured data. The information gathered throughout the course was used to support the objectives for the investigative research that was completed.

\subsection{Participants}

The participants of this research were a group of 30 university students studying to be elementary school teachers. They participated in the research for two semesters or one year of college. These students were in their third and fourth semester of study at UNAE in Ecuador. The author of this paper was able to conduct this research with the group and follow their progress throughout the beginner level course. Through the participation of the students in discussions, questionnaires and assessment tools the teacher was able to create valid research on the subject being discussed throughout the paper.

\subsection{Sampling Procedures}

The participants of this research were chosen as the subject of study as they are a group of 30 students who have various needs, which create differing learning styles. The entire beginner class was used as the sample over a 9-month period. These students were chosen to show their diversity in ways of learning and reasons they were taking English which ultimately effected and impeded their motivation for advancing in language learning.

\subsection{Instruments and Data Analysis}

The instruments used, allowed for student feedback through class discussions in the beginning of each semester, a learning style multiple choice test online called What's your Learning Style? 20 Questions (n.d) was given on the first day of class, questionnaires consisting of multiple questions at the beginning of each semester and one at end of each semester and assessment activities to monitor the student's advancement in learning the tasks and new information given were also administered. The questionnaire given out on the first day was called The Importance of English and was made by the English professor of the group participating in the study. It asked students about their reasons for taking English, why the students think it is important to learn English, strategies used in previous English language courses they attended, personal opinions about those courses and if they think being proficient in English will help them in the future. The questionnaire given at the end of the course was called Games and Various Strategies Used in Class and their Importance. This was also created by the professor of the course where the investigation took place. It asked questions about what teaching strategies the students felt they learned the most from, what types of activities they enjoyed, and personal opinions about what and how they learned over the semester. These questionnaires were a combination of ideal, interpretative, hypothetical and provocative qualitative research questions. The teacher also shared information with other teachers and received feedback from different professors teaching the same level of students, but not teaching to their specific learning styles or using games in the classroom as a motivational and learning strategy. Through these investigative instruments the professor was able to gather sufficient information to create conclusions and obtain results for the research that was conducted.

\subsection{Validity and Reliability}

The validity of the online test was shown as a statistical chart using the information of the students as a predictive validity source, so the teacher had the necessary information to create games and activities to advance student language learning based on their specific learning styles throughout the course. This is a reliable test as it is individualized and will show similar results in future investigation depending on the students learning style. The questionnaires used at the 
beginning and end of the course were reliable investigative tools for university level students of UNAE in Ecuador. They asked questions focused on participants of this country and region. Assessment exams supported these findings through students increased knowledge when they participated in activities that were created for their specific learning style. The assessment tools used were reliable standardized exams and quizzes from the Cambridge Touchstone Series for English language learning by McCarthy (2014). These exams measured students' knowledge for the advanced beginner level and reading, writing, listening and speaking skills practiced and learned throughout the course. The valid statistical analysis of the questionnaires gave the professor the necessary information to move forward and provide answers to the research question being investigated in this paper. The discussions with academic peers gave a valid correlation to how results would change based on teaching to students learning styles and the use of strategies to motivate students or not. These results are fairly reliable depending on teacher strategies and levels of student proficiency in English. The assessment tools were important to give concrete evidence of how games supported and increased student's ability to use the new information taught, internalize it and most importantly advance in the English language learning process. The tools used in this research are reliable information gathering tools for this group of particular students as they analyze their specific situation in UNAE in Azogues, Ecuador to give information to support the results found in this paper.

\subsection{Data Analysis}

The investigation completed in this paper was based on qualitative research through the approach. The research question is fairly flexible as education can change with different students and situations. This research focuses on a small sample of students over a relatively short amount of time. The data was collected in the classroom and was free from a controlled setting. This created more natural data stemming from participatory action research in an academic English language classroom. The data collected is related to the opinions of the individual students, results from assessment tools and information gathered from interviews with academic peers of the same discipline. The questions asked in the research where varied, but mainly were open-ended questions to aid in narrowing the results. Students learning styles coded this information depending on the results of the quizzes administered in the beginning of the courses and opinions and answers to the questionnaires. Games were then chosen depending on the information gathered about the participants' of the study and the results depended on these groups of learners.

\subsection{Implementation of Games}

This paper focuses on 4 different types of games. These games support different learning styles, provide students with internal motivations, create a more authentic environment, connect grammar and vocabulary to various skills and increase student's English language abilities. The games being focused on are small group speaking and listening games, board games, board rush competitions and charades.

\section{Speaking Game}

An example of a game that was played was called Famous Name Game. Students would write the name of a famous person on a small piece of paper. Then they would tape the paper to a group member's forehead with the person knowing what name was on the paper. When everyone had a name taped to their forehead they would take turns asking yes or no questions to gain clues about who they were. Each person is allowed to ask three yes or no questions. If they cannot guess the name on the paper, the next person goes and so on. This is repeated until everyone guesses the name on his or her paper. This game motivates students to use English so they can ask questions to get more information about the famous person. Students also are practicing speaking and listening skills while reinforcing the previously learned grammar. This game helps students be more comfortable speaking, as they tend to forget their insecurities through game play. This also helps students who are audio learners thrive, as this is a speaking only activity.

\section{Boardgame}

The board game used for this class was to practice and reinforce past simple wh-questions. Students were placed in groups of 3-4 students. They were given a dice and the board game. The board game had time words and activity words. Students had to roll the die and move to the number on the die on the board. They then read the time word and activity word out loud. Next they had to create a wh-question using those words in past tense. For example the box said study/ yesterday, the students had to create questions, such as "What did you study yesterday?" If the other students participating deemed the question correct they stayed at the same space, otherwise they must go back to the space they were at on the board. Students then repeat the process until one of them gets to the end first. This type of game also intrinsically motivates the student to speak and use English because they must form correct questions to be able to move forward in the game. This also aids in visual or audio learning styles. They can see the words and listen to their peers speak at the same time. 


\section{Board Rush}

An example of this game that was used with this group was for the prepositions of this, these, that and those and types of clothing. The class was divided into two groups. The teacher had a pre-prepared slide show using individual slides with one article of clothing or more where students raced to write the correct answer. One student from each team would run to the board to write a sentence using the correct preposition and name of clothing. The student that wrote the correct answer first would get a point for their team. This game not only motivated the students to use the correct words, but also helped them work together in their teams, since they had to find the correct answer together.

\section{Charades}

Playing charades was used in the author's class to reinforce grammar about everyday activities and the present continuous. The students would play this game to reinforce previously learned grammar and vocabulary. They would play this game in two teams as an entire class. The teacher would write down different activities in the present simple on small pieces of paper. One student would come to the front of the class and choose a piece of paper. This student would then act the activity out. The whole class would try and guess what the student was doing using present continuous in a complete sentence. The first student to guess the correct answer in the correct form would win a point for their team. They would then be the next student to act out an activity in front of the class. This type of activity also supported the kinesthetic learners in the class who learn better through movement. Charades was also a good way for students of this group to relax and almost forget they were learning grammar, by just participating in the game.

\section{Findings and Results}

The findings of the study have shown how games increased the students' abilities to speak in simple guided conversations, advanced their language learning to the next level of A2.1 according to the European Common Framework (n.d), allowing students to become advanced beginners. Students gain more intrinsic motivation to learn English, since they began to enjoy language learning through the teacher's use of language games in the classroom. Games also helped the students remember and use the language correctly in other situations, which was another motivating factor that resulted from the strategies discussed in this paper. In the charts below the teacher shows the findings from the research completed about the students learning styles, motivation of the students and promotion of the pupils English language skills through the method of games.

\subsection{Statistical Analysis}

Table 1 gives the results of the online quiz and shows the reason for the types of games that were chosen by the teacher of the group discussed in this paper. The teacher chose games depending on the types of learning styles of the students to teach more directly to the student's needs, so they ultimately are able to advance in language learning

Table 1. Online Quiz Results for Learning styles

\begin{tabular}{lllll}
\hline 30 & Physical/movement & Visual & Oral & Audio \\
\hline $\begin{array}{l}\text { Number of students } \\
\text { who learn in this }\end{array}$ & 17 & 8 & 2 \\
form
\end{tabular}

The questionnaire below was administered at the end of class to find out how students previous experiences with English, how they felt about learning English and if they were motivated to learn English. 


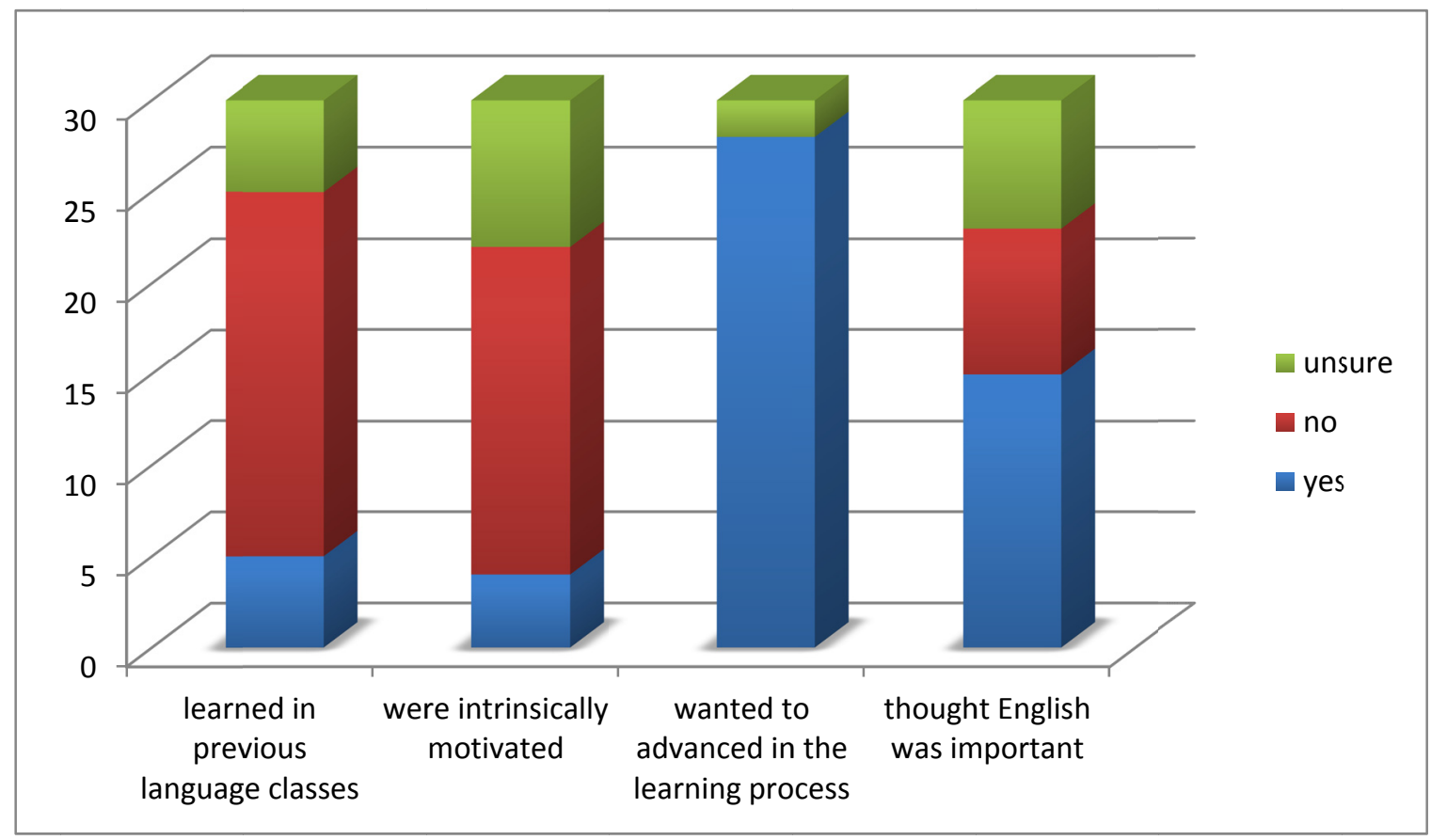

Figure 1. Questionnaire 1

This chart below shows the results of the percentage of the opinions of the students who enjoyed playing games, want to learn more English and have found intrinsic reasons to learn English in the future.

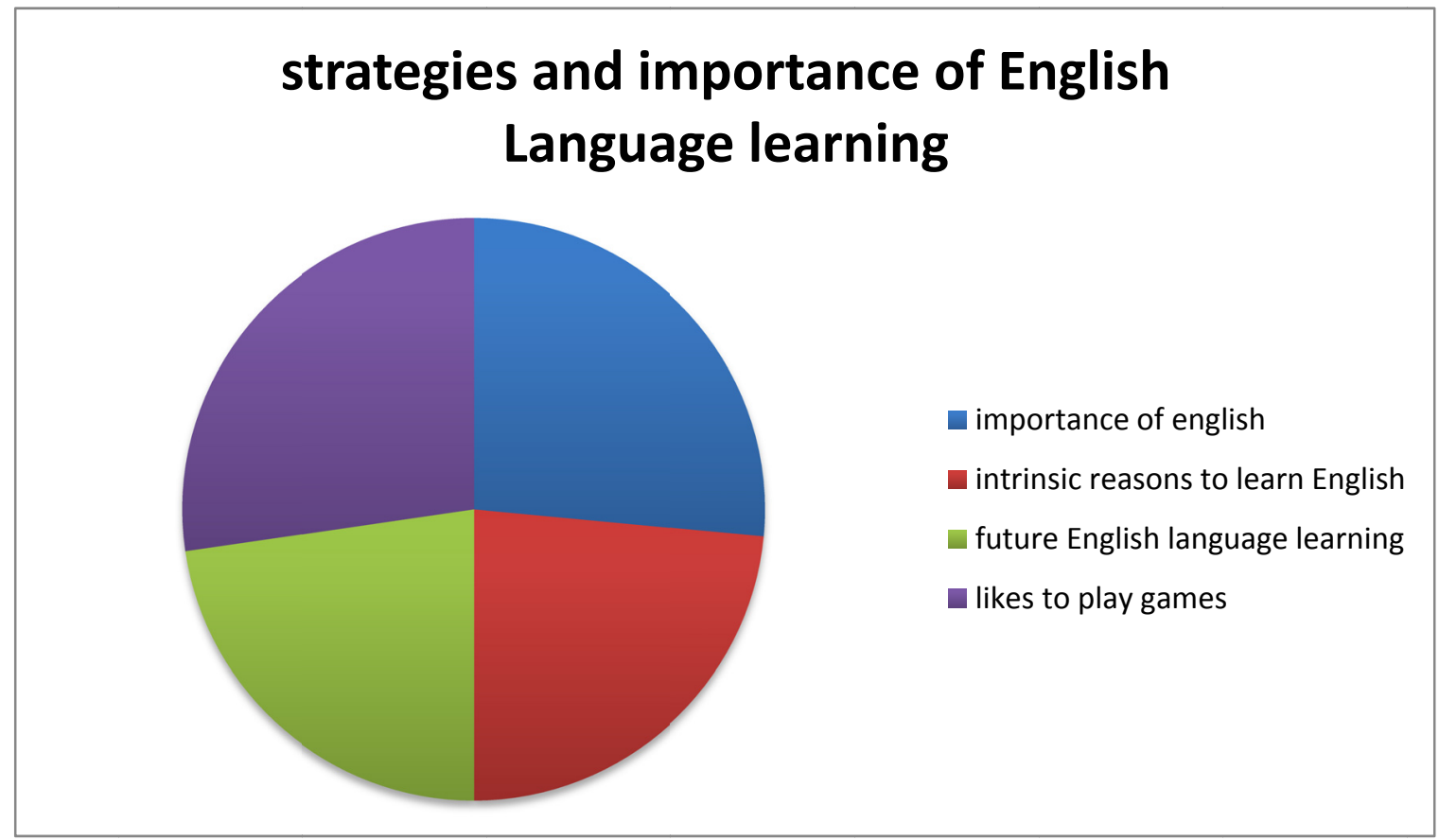

Figure 2. Questionnaire 2

The Figure 3 below expresses the findings about how students advanced in their English language learning and internalized the grammar and vocabulary previously learned in the class through the use of games. The result of the students' work illustrates how they have increased their knowledge and have a better understanding of the language skills. The teacher found these results through standardized exams from the touchstone series mentioned above. 


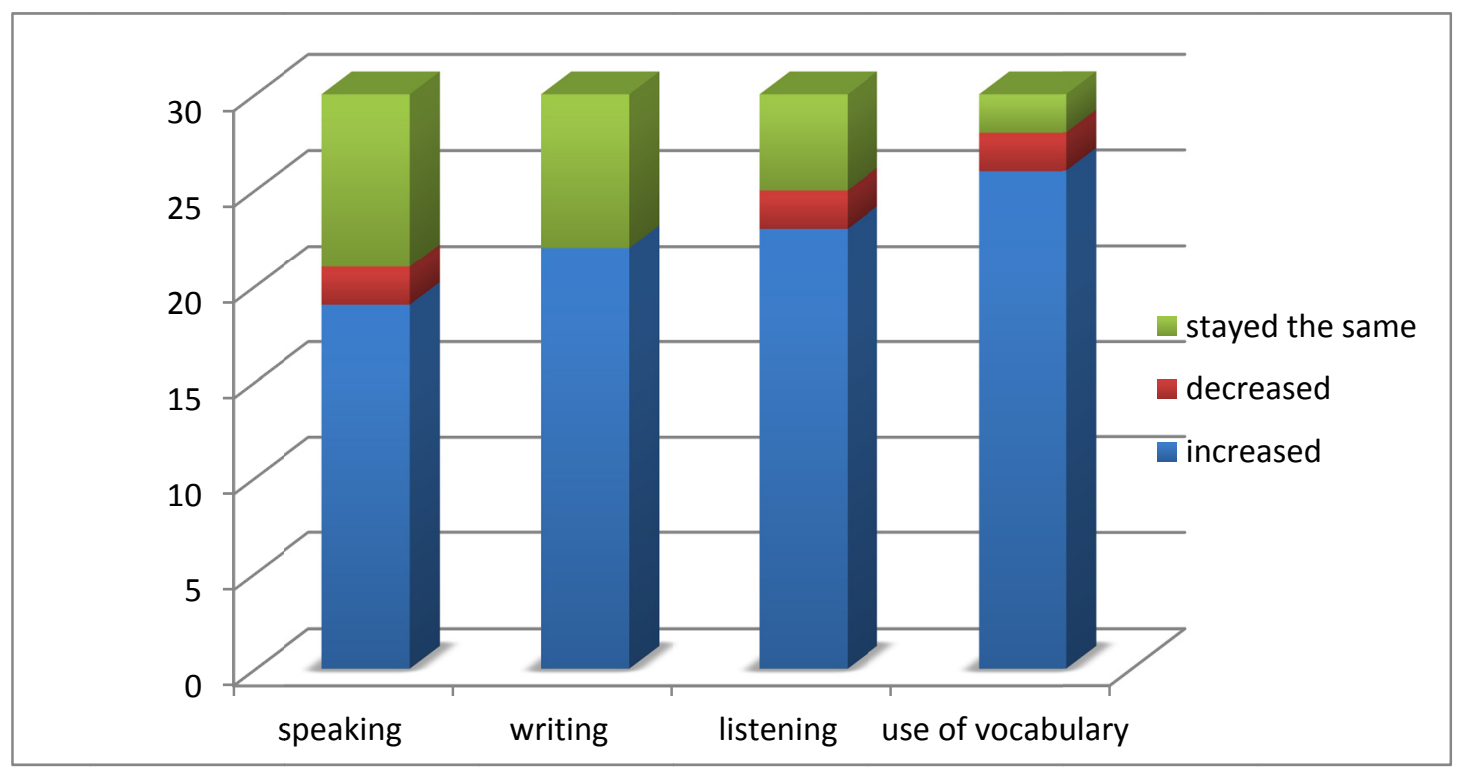

Figure 3. Assessment

\section{Discussion}

The professor found that using games in the classroom allowed for students to understand the information being taught through a medium that increased the likely hood students would be intrinsically motivated and opened the door to learn in various styles depending on the needs of the students. There are many different types of games that can be played in an English language class. Some examples of other types of games are discussed by Kim (1995) who gives examples used to practice various skills in an English language classroom to aid in students enjoyment in the learning process. Another researcher who believes that games are necessary in an English language class is Dhumal (2015). Dhumal (2015) completed a study in India and reiterates the idea that there are endless amounts of games a teacher can create for all areas of English language learning. These are just a few studies completed to support the strategy of using games when teaching language.

The first effective educational game used by the teacher was a speaking game. Students worked in small groups to practice tenses and new vocabulary in the research. These games allowed the students to speak in a more comfortable and relaxed setting, ultimately motivating them to practice the previously learned knowledge. Wörde (2003) completed a study citing students' opinions of activities, which can help reduce anxiety. These opinions expressed how games could be a good learning strategy for students to feel more relaxed and be able to learn the language. (Wörde, 2003) The author of this paper found when students were speaking while playing a game they were much more relaxed and able to communicate with their peers using the previously learned structures correctly. However, when the teacher directly asked the student to speak in class many of the same students had a much harder time speaking using the correct grammar and structural patterns outside of game play. In the games played in the study students were given the opportunity to speak freely while receiving the support of their peers. This cooperative activity helped them practice creating sentences and questions. It also helped them forget they were learning English and take pleasure in participating in the language class.

Another type of game used in the classroom to support the authors findings were board games to practice grammar, structure, usage and vocabulary in English. This type of game created an authentic setting of just friends spending time together doing a fun activity. Talik-Kiryk (2010) explains how games tend to be played in groups and allow for independent student communication, while the students are supporting each other and working together to move forward in the language learning process. In the authors class, this task was completed in small groups of three to four students. Working together created a space that promoted natural language learning in a collaborative setting. The board games used by the teacher, helped students use specific sentence structures for speaking and listening skills. They also practiced reading skills to be able to participate in the game. Board games allowed the participants of this study to practice various skills without being focused on grammar and vocabulary. Chang and Cogswell (2008) specifically discussed how board games could allow students to practice these skills, but in a conscious setting where students can have fun and unknowingly use the grammar and vocabulary previously taught through communication while playing the game.

Many people thrive in competitive environments. Vandercruysse, Vandewaetere, Cornillie, \& Clarebout (2013) have 
found through research that competition is important because it can challenge students and when they are challenged it can create more motivation, students can be more responsive, more engaged, and more enthusiastic about participating and learning. The English language class studied did not differ in this aspect. Competitive games connected to English language learning intrinsically motivated the participants through human emotions and competitive forces. Board rushes help to reinforce many aspects of English by putting the students into teams allowing them to compete against each other for the correct answers. This also supported the more physical or kinesthetic learners in the class. Students must run to the board to write the answers allowing for movement in the task. These games motivated the students to begin to internalize and practice parts of speech and vocabulary.

Adams (2011) points out how many students can have a difficult time retaining new vocabulary when they are kinesthetic learners, but when they are able to learn through movement they have an increased chance to understand, comprehend and remember the vocabulary when it is practiced in class. The English teacher for this group of students chose to play the game of charades to enhance the learning process for the few kinesthetic learners in the class mentioned in this paper. These students were able to create English through acting and physical movement to express what they understood to their peers and aid in internalizing the new language they previously learned. This game can be used to practice vocabulary, tenses and sentence structure. Students also used various skills such as speaking, reading and listening when completing this task.

It can be seen through the discussion and from the findings and results section that students not only increased their knowledge and abilities, but also felt more motivated and showed excitement to learn through the use of games in the EFL classroom. Students from this group supported the teachers' research when they answered the questionnaire positively. They reiterated the professor's ideas that games are a helpful method in promoting language learning inside the classroom, increased individual and group motivation to learn and succeed, created meaningful connections for authentic language situations, and supported various types of learning styles. Through the results it is also seen how game play with this group of students increased the students' abilities in all of the English language skills practiced playing games, while utilizing different styles of learning to promote students' correct English language usage. It can be recognized through the research completed in this paper that games are not only a good teaching method, but also a great learning strategy and motivational tool for students in an English language classroom, specifically in UNAE in Ecuador.

\section{References}

(n.d.) Common European Framework of Reference for Languages: Learning, Teaching, Assessment. Retrieved from http://www.coe.int/t/dg4/linguistic/Source/Framework_EN.pdf

(n.d.) What's your Learning Style? 20 Questions. Retrieved from http://www.educationplanner.org/students/self-assessments/learning-styles-quiz.shtml

Adams, D. (2011). Accelerating Learning with Kinesthetic Vocabulary Activities. Retrieved from http://info.marygrove.edu/MATblog/bid/65859/Accelerate-Learning-with-Kinesthetic-Vocabulary-Activities

Arikan, A., \& Yolagelddili, G. (2011). Effectiveness of Using Games in Teaching Grammar to Young Learners. $\begin{array}{lllll}\text { Elementary } \quad \text { Education } & \text { Online, } & \text { 10(1), } 229 . & \text { Retrieved from }\end{array}$ http://ilkogretim-online.org.tr/vol10say1/v10s1m18.pdf

Beyan, O., Çekiç A., \& Köksal, O. (2014). Views Of Turkish EFL Students With Regard To Learning GRammar with Games, International Journal on New Trends in Education and Their Implications, 5(1), 82-91. Retrieved from http://docplayer.net/13250871-Views-of-turkish-efl-students-with-regard-to-learning-grammar-with-games.html

Chang, S., \& Cogswell, J. (2008) Using Boardgames in the Language Classroom. TESOL 2008. Retrieved from www.rtmsd.org/cms/lib9/PA01000204/.../57/Using_Board_Games_Handout.doc

Chen, I. (2005). Using Games to Promote Communicative Skills in Language Learning. The Internet TESOL Journal, 11(2). Retrieved from http://iteslj.org/Techniques/Chen-Games.html

Deesri, A. (2002). Games in the ESL and EFL class. The Internet TESL Journal, 8(9). Retrieved from http://iteslj.org/Techniques/Deesri-Games.html

Dhumal, M. (2015). Gaming and Simulation in English Language Teaching: A Symbiotic Interweave Towards Language Efficiency. International Conference on Language Learning and Teaching at HCT Dubai's Men's College, 8(1). Retrieved from http://www.21 caf.org/uploads/1/3/5/2/13527682/59-64.dhumal.pdf

Dunlap, D. (2013). Games and Ice Breakers for the ESL classroom. Retrieved from http://www.fulbright.cz/sites/default/files/soubory/gamesicebreakers.pdf

Elliot, J. (2004). 6 Group Activities for Teaching ESL children. The Internet TESL Journal, 10(4). Retrieved from 
http://iteslj.org/Lessons/Elliott-GroupActivities.html

Ersoz, A. (2000) Games for the EFL/ESL Classroom. The Internet TESL Journal, 6(6). Retrieved from http://iteslj.org/Lessons/Ersoz-Games.html

Kim, S. L. (1995). Creative Games for the Language Class. Forum, 33(1). http://dosfan.lib.uic.edu/usia/E-USIA/forum/vols/vol33/no1/P35.htm

Lombardi, M. M. (2007). Authentic Learning for the $21^{\text {st }}$ century: An Overview. Retrieved from https://library.educause.edu/resources/2007/1/authentic-learning-for-the-21st-century-an-overview

McCarthy, M. (2014). Touchstone: Level 1 teacher's edition with assessment audio. Cambridge University Press.

Moon, K., \& Reifel, S. (2008). Play and Literacy Learning in a Diverse Language Pre-Kindergarten Classroom. Contemporary Issues in Early Childhood, 1(9). https://doi.org/10.2304/ciec.2008.9.1.49

Mubaslat, M. M. (2012). The Effect of Using Educational Games on the Students' Achievement in English Language for the Primary Stage. Retrieved from http://files.eric.ed.gov/fulltext/ED529467.pdf

Nguyen, T. T. H., \& Khuat, T. T. N. (2003). Learning Vocabulary Through Games: The Effectiveness of Learning Vocabulary Through Games. The Asian EFL Journal, 5(4).

Rao, Z. (2006). Understanding Chinese Students' Use of Language Learning Strategies from Cultural and Educational Perspectives. Journal of Multilingual and Multicultural Development 6(6). Retrieved from https://doi.org/10.2167/jmmd449.1

Republica Del Ecuador Consejo de Educacion Superior RPC-SE-13-No.051-2013. Retrieved from http://www.ces.gob.ec/index.php?option=com_phocadownload\&view=category\&id=12\&Itemid=303

Shahzad, A. (2011). The use of authentic games in English language teaching. Ekev Academic Review, 15(47). Retrieved from http://connection.ebscohost.com/c/articles/83752324/use-authentic-games-english-language-teaching

Shultz, R. (2011). Stephen Krashen's Theory of Second Language Acquisition. Retrieved from http://www.sk.com.br/sk-krash.html

Sigurðardóttir, S. D. (2010). The use of game in the English language classroom. Retrieved from http://skemman.is/stream/get/1946/6467/13457/1/Sigridurdogg2010.pdf

Talak-Kiryk, A. (2010). Using Games In A Foreign Language Classroom. MA TESOL Collection. Paper 484

Vandercruysse, S., Mieke, V. M., Cornillie, F., \& Clarebout, G. (2013). Competition and students' perceptions in a games-based language learning environment. Education Tech Research Dev. 61, 927-950. https://doi.org/10.1007/s11423-013-9314-5

Wörde R. V. (2003). Students' Perspectives on Foreign Language Anxiety. Inquiry, 8(1). Retrieved from http://files.eric.ed.gov/fulltext/EJ876838.pdf

\section{Copyrights}

Copyright for this article is retained by the author(s), with first publication rights granted to the journal.

This is an open-access article distributed under the terms and conditions of the Creative Commons Attribution license which permits unrestricted use, distribution, and reproduction in any medium, provided the original work is properly cited. 